\title{
COMPARISON OF SERUM LIPOPROTEIN (A) LEVEL IN TYPE 2 DM AND NON-DIABETIC PATIENTS WITH ACUTE CORONARY SYNDROME
}

\author{
Subhash Chand Meena ${ }^{1}$, Girish Chandra Verma ${ }^{2}$, C. P. Meena ${ }^{3}$, S. R. Meena ${ }^{4}$, Abdul Wahid Qureshi5, A. R. Pathan ${ }^{6}$, Fazil Hussain ${ }^{7}$ \\ ${ }_{1}^{1}$ Postgraduate Resident, Department of Medicine, Government Medical College, Kota, Rajasthan, India. \\ ${ }^{2}$ Senior Professor and Unit Head, Department of Medicine, Government Medical College, Kota, Rajasthan, India. \\ ${ }^{3}$ Professor, Department of Medicine, Government Medical College, Kota, Rajasthan, India. \\ ${ }^{4}$ Senior Professor and HOD, Department of Medicine, Government Medical College, Kota, Rajasthan, India. \\ ${ }_{5}^{5}$ Assistant Professor, Department of Medicine, Government Medical College, Kota, Rajasthan, India. \\ ${ }^{6}$ Medical Officer, Department of Medicine, Government Medical College, Kota, Rajasthan, India. \\ 7Postgraduate Resident, Department of Medicine, Government Medical College, Kota, Rajasthan, India.
}

\section{BACKGROUND}

\section{ABSTRACT}

Coronary artery disease has multifactorial origin including hereditary and acquired risk factors. Newer risk factors which are elevated in Indian population include Lp (a), CRP and homocysteine levels. Lipoprotein (a) levels are consistently elevated in Indian population compared to other ethnic groups.

The aim of this study is to estimate lipoprotein (a) level in type 2 diabetic and non-diabetic patients with acute coronary syndrome and to correlate its levels with severity of ACS.

\section{MATERIALS AND METHODS}

The present study was a case control study, conducted at MBS Hospital, Kota. The sample size was 50 in each group. 50 patients were type 2 diabetics and 50 patients were non-diabetics. They were categorised as Unstable Angina, NSTEMI and STEMI groups. $\mathrm{Lp}(\mathrm{a})$-C estimation was performed with EDC Helena electrophoretic analyser. Lp(a) was calculated from Lp(a)-C by multiplying with 3.

\section{RESULTS}

Lp(a) level was significantly higher in type 2 diabetics compared with non-diabetic group (15.15 \pm 5.3 vs $11.93 \pm 5.7$, p < 0.02 ) More number of diabetics had Lp(a)-C level $>10 \mathrm{mg} / \mathrm{dL}$ than non-diabetic group. This difference was found to be significant (82\% vs 38, p < 0.05). Lp(a)-C levels in all three subgroups of ACS (NSTEMI; $12.85 \pm 4.57$ vs $11.05 \pm 5.3$, STEMI; $16.61 \pm 3.11$ vs $11.21 \pm$ 5.8, UA; $15.76 \pm 7.39$ vs $13.61 \pm 6.2$ ) were significantly more in diabetic group compared to non-diabetic group (p $<0.05)$. Further $\mathrm{Lp}(\mathrm{a})-\mathrm{C}$ levels were more in STEMI group $(\mathrm{p}<0.001)$ compared to NSTEMI $(\mathrm{p}<0.030)$ and unstable angina group $(\mathrm{p}<0.002)$. The diabetic group had a significantly higher BMI (27.37 \pm 3.39 vs $22.90 \pm 2.4, \mathrm{p}<0.05)$ and Waist Circumference $(97.14 \pm 4.93$ vs 92.28 $\pm 5.90, \mathrm{p}<0.04$ ) as non-diabetic group, in which males had a significantly higher waist circumference compared to females (90.64 \pm 5.20 vs $85.54 \pm 3.55, \mathrm{p}<0.05$ ). Cardiac biomarkers (CK-MB, $80.32 \pm 57.55$ vs $62.56 \pm 44.81$; Troponin T, $0.021 \pm 0.020$ vs $0.014 \pm$ $0.0002, \mathrm{p}<0.05)$ and random blood sugar $(180.04 \pm 46.75$ vs $119.84 \pm 18.99, \mathrm{p}<0.05)$ were significantly higher in the diabetic as compared to non-diabetic group.

\section{CONCLUSION}

Type 2 diabetic patients had 2.15-fold higher chance of having $\mathrm{Lp}(\mathrm{a})-\mathrm{C}>10 \mathrm{mg} / \mathrm{dL}$ than non-diabetic individual. Lp(a) may contribute to the higher risk of having CAD in type 2 diabetics as compared to non-diabetics. Higher level of Lp(a) directly correlates with severity of myocardial injury.

\section{KEY WORDS}

Lipoprotein (a), Lipoprotein (a)-C, Acute Coronary Syndrome, Type 2 DM.

HOW TO CITE THIS ARTICLE: Meena SC, Verma GC, Meena CP, et al. Comparison of serum lipoprotein (A) level in type 2 DM and non-diabetic patients with acute coronary syndrome. J. Evolution Med. Dent. Sci. 2018;7(29):3304-3307, DOI: $10.14260 /$ jemds/2018/744

\section{BACKGROUND}

Acute myocardial infarction is one of the most common diagnosis in hospitalised patients in industrialised countries. ${ }^{1}$ Cardiovascular disease has emerged as major health problem worldwide. Coronary artery disease has multifactorial origin including hereditary and acquired risk factors. ${ }^{2}$

'Financial or Other Competing Interest': None.

Submission 07-05-2018, Peer Review 30-06-2018,

Acceptance 07-07-2018, Published 16-07-2018.

Corresponding Author:

Dr. Subhash Chand Meena,

Village Saray, Post-Gandal,

Tehsil-Bamanwas-Dist. Sawaimadhopur-322204,

Rajasthan, India.

E-mail: dr.subhashsms@gmail.com

DOI: $10.14260 / \mathrm{jemds} / 2018 / 744$

\section{(c) (1) $(9)$}

The Lp(a) concentration was higher in patients who died from cardiovascular disease in comparison with those who remain alive or those who died from non-cardiovascular disease in a large 9-year prospective study in 1993 by Hernandez et al on 122 consecutive patients with type 2 DM attending diabetic unit in Barcelona. ${ }^{3}$

Type $2 \mathrm{DM}$ is associated with significant cardiac morbidity and mortality with a more than three-fold increase risk of coronary artery disease. However, this increased cardiovascular risk is only partially explained by conventional risk factors like hypertension, lipid abnormalities, central obesity and glucose intolerance. ${ }^{4}$ Newer risk factors which are elevated in Indian population in a comparative study include Lp(a), CRP and Homocysteine levels. ${ }^{2}$ Lipoprotein (a) levels were consistently elevated in Indian population compared to other ethnic group. ${ }^{5}$ 


\section{Objective}

The aim of this study is to estimate lipoprotein (a) level in type 2 diabetic and non-diabetic patients with acute coronary syndrome and to correlate its levels with severity of ACS.

\section{MATERIALS AND METHODS Study Design}

This study is case control study.

All the subjects under study were recruited from MBS Hospital, Kota, in year 2017 after obtaining informed consent. All the patients in the diabetic group were confirmed diabetics, who were either diagnosed as per ADA criteria or were receiving treatment for diabetes mellitus. A detailed history was taken and examination and relevant investigations done.

\section{Following Investigations were Conducted-}

A. Routine investigations (done for all cases): ECG in all 12 leads, Blood Sugar (BS) at the time of admission, Serum Lipoprotein (a) and other routine investigations done.

B. Special investigations: HbA1c, Microalbuminuria.

\section{The Study Population consisted of 50 Age and Sex} Matched Cases and Controls-

1. Type 2 Diabetics with acute coronary syndrome.

2. Non-diabetic patients with acute coronary syndrome.

Patients with type 2 diabetes mellitus having ACS were taken as cases and non-diabetics with ACS considered as controls.

Selection of case and control was made on "first come and first find" basis. The patients who report first in hospital was included in the study after applying exclusion and inclusion criteria in year 2017 till sample size achieved in both groups.

\section{Inclusion Criteria}

Patients with angina of duration more than 30 minutes, but within 24 hours from onset of angina including both Type 2 diabetic and non-diabetic patients.

\section{Exclusion Criteria}

- Angina secondary to extracardiac causes, eg. Anaemia, thyrotoxicosis.

- Pre-diabetes (Impaired fasting glucose and impaired glucose tolerance) patients were excluded from both groups.

- $\quad$ Any type of renal failure.

- Nephrotic syndrome.

- $\quad$ Type 1 diabetes mellitus.

- Liver disease.

- Post-myocardial infarction angina.

- Treatment history of drug that alter serum LP(a) level, e.g. Aspirin, Hypolipidemic drugs, Oral contraceptive pill, Oestrogen replacement therapy and Antiepileptic drugs.

- Patients refused to give informed consent for the study.

Sample size was calculated by using online calculator for comparing two means by student's t-test, in which R Salehi et al study mean level for serum Lp(a)-Type 2 Diabetic $16.8 \pm 4.4$ and for non-diabetic $13.3 \pm 5.1$ was taken as $\mu 1$ (mean for population 1) and $\mu 2$ (mean for population 2) and 5.1 was taken as common standard deviation. By applying two-sided test using 90 percent power and 5 percent $\alpha$ error, sample size was calculated as 45 in each group which was rounded off to 50 in each group.

\section{Statistical Analysis}

Statistical analysis was done by using percentages, mean values, standard deviation, chi-square test and student t-test. A p-value $<0.05$ level was considered statistically significant and a p-value > 0.05 was considered as statistically insignificant. All statistical analysis was done using SPSS 16.0.

\section{RESULTS}

In diabetic patients, maximum value of $\mathrm{Lp}(\mathrm{a})-\mathrm{C}$ was seen in 51 - 60 years age group, while minimum value of $\mathrm{Lp}(\mathrm{a})-\mathrm{C}$ was seen in 31 - 40 years age group. $82 \%$ of diabetics had Lp(a)-C $>10 \mathrm{mg} / \mathrm{dL}(\mathrm{p}<0.05)$ (Table 1$)$. In non-diabetic patients, minimum value of $\mathrm{Lp}(\mathrm{a})-\mathrm{C}$ was seen in $61-70$ years of age group and 38\% of non-diabetics had Lp(a)-C $>10 \mathrm{mg} / \mathrm{dL}$ (Table 2). The diabetic group had a significantly higher mean BMI and Waist Circumference as compared to non-diabetic group ( $\mathrm{p}<0.05)$, in which males had a significantly higher Waist Circumference compared to females $(\mathrm{p}<0.05)$ (Table 3). Cardiac biomarkers and random blood sugar were significantly higher in the diabetic as compared to the nondiabetic group $(\mathrm{p}<0.05)$ (Table 4). Serum Lp(a)-C, Total Cholesterol, Triglyceride and VLDL were significantly higher in type 2 diabetic group when compared to non-diabetic group $(\mathrm{p}<0.05)$ except HDL-C, which was significantly lower in type 2 diabetic group than non-diabetic group ( $<<0.05)$, while LDL-C was higher in type 2 diabetics but not statistically significant (Table 5). Mean Lp(a)-C in all three subgroups of ACS were significantly more in diabetic group compared to non-diabetic group $(p<0.05)$. Lp(a)-C levels were more in STEMI $(\mathrm{p}<0.001)$ group compared to NSTEMI and unstable angina group (Table 6).

\begin{tabular}{|c|c|c|c|c|c|c|c|c|c|c|c|c|}
\hline \multirow{2}{*}{$\begin{array}{c}\text { LP(a)-C } \\
\text { (mg/ } \\
\text { dL) }\end{array}$} & \multicolumn{2}{|c|}{$\begin{array}{c}21-30 \\
\text { Yrs. }\end{array}$} & \multicolumn{2}{|c|}{$\begin{array}{c}31-40 \\
\text { Yrs. }\end{array}$} & \multicolumn{2}{|c|}{$\begin{array}{c}41-50 \\
\text { Yrs. }\end{array}$} & \multicolumn{2}{|c|}{$\begin{array}{c}\text { 51-60 } \\
\text { Yrs. }\end{array}$} & \multicolumn{2}{|c|}{$\begin{array}{c}\text { 61-70 } \\
\text { Yrs. }\end{array}$} & \multicolumn{2}{|c|}{$\begin{array}{l}>70 \\
\text { Yrs. }\end{array}$} \\
\hline & $\mathbf{N}$ & $\%$ & $\mathbf{N}$ & $\%$ & $\mathbf{N}$ & $\%$ & $\mathbf{N}$ & $\%$ & $\mathbf{N}$ & $\%$ & $\mathbf{N}$ & $\%$ \\
\hline $0-5$ & 0 & 0 & 1 & 10 & 0 & 0 & & 0 & 0 & 0 & & 0 \\
\hline$>5-10$ & 0 & 0 & 1 & 10 & 2 & 18 & 4 & 27 & 1 & 14 & 0 & 0 \\
\hline$>10-15$ & 1 & 25 & 3 & 30 & 1 & 9 & & 40 & 4 & 57 & & 33 \\
\hline$>15-20$ & 2 & 50 & 2 & 20 & 7 & 64 & 3 & 20 & 1 & 14 & 0 & 0 \\
\hline$>20-25$ & 1 & 25 & 3 & 30 & 1 & 9 & 0 & 0 & 1 & 14 & 2 & 67 \\
\hline$>25-30$ & 0 & 0 & 0 & 0 & 0 & 0 & 2 & 13 & 0 & 0 & 0 & 0 \\
\hline Total & 4 & & 10 & & 11 & & 15 & & 7 & & 3 & \\
\hline
\end{tabular}

Table 1. Distribution of Lp (a)-C Levels in different age group of Diabetic Patients

\begin{tabular}{|c|c|c|c|c|c|c|c|c|c|c|c|c|}
\hline \multirow{2}{*}{$\begin{array}{c}\text { LP(a)- } \\
\text { C } \\
\text { (mg/ } \\
\text { dL) }\end{array}$} & \multicolumn{2}{|c|}{$\begin{array}{c}21-30 \\
\text { yrs. }\end{array}$} & \multicolumn{2}{|c|}{$\begin{array}{c}31-40 \\
\text { yrs. }\end{array}$} & \multicolumn{2}{|c|}{ 41-50 yrs. } & \multicolumn{2}{|c|}{ 51-60 yrs. } & \multicolumn{2}{|c|}{$\begin{array}{c}\text { 61-70 } \\
\text { yrs. }\end{array}$} & \multicolumn{2}{|c|}{$\begin{array}{c}>70 \\
\text { yrs }\end{array}$} \\
\hline & $\mathbf{N}$ & $\%$ & $\mathbf{N}$ & $\%$ & $\mathbf{N}$ & $\%$ & $\mathbf{N}$ & $\%$ & $\mathbf{N}$ & $\%$ & $\mathbf{N}$ & $\%$ \\
\hline $0-5$ & 0 & 0 & 0 & 0 & 0 & 0 & 0 & 0 & 1 & 10 & 0 & 0 \\
\hline$>5-10$ & 2 & 67 & 4 & 40 & 7 & 64 & 8 & 61 & 6 & 50 & 3 & 75 \\
\hline $\begin{array}{c}>10- \\
15\end{array}$ & 0 & 0 & 1 & 10 & 0 & 0 & 1 & 7.7 & 1 & 20 & 0 & 0 \\
\hline $\begin{array}{c}>15- \\
20\end{array}$ & 0 & 0 & 2 & 20 & 2 & 18 & 3 & 23 & 1 & 10 & 0 & 0 \\
\hline $\begin{array}{c}>20- \\
25\end{array}$ & 1 & 33 & 3 & 30 & 1 & 9 & 1 & 7.7 & 1 & 10 & 1 & 25 \\
\hline $\begin{array}{c}>25- \\
30\end{array}$ & 0 & 0 & 0 & 0 & 0 & 0 & 0 & 0 & 0 & 0 & 0 & 0 \\
\hline Total & 3 & & 10 & & 10 & & 13 & & 10 & & 4 & \\
\hline & & . & & in 1 & 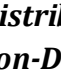 & & & oup & & & & \\
\hline
\end{tabular}




\begin{tabular}{|c|c|c|c|}
\hline Parameter & $\begin{array}{c}\text { Group I } \\
\text { Mean } \pm \text { SD }\end{array}$ & $\begin{array}{c}\text { Group II } \\
\text { Mean } \pm \text { SD }\end{array}$ & P-Value \\
\hline $\begin{array}{c}\text { Mean BMI } \\
\text { (kg/sq.m) }\end{array}$ & $27.37 \pm 3.39$ & $22.90 \pm 2.4$ & 0.02 \\
\hline $\begin{array}{c}\text { Mean Waist } \\
\text { Circumference } \\
\text { Males (cms) }\end{array}$ & $97.14 \pm 4.93$ & $92.28 \pm 5.90$ & 0.04 \\
\hline $\begin{array}{c}\text { Mean Waist } \\
\text { Circumference } \\
\text { Females (cms) }\end{array}$ & $90.64 \pm 5.20$ & $85.54 \pm 3.55$ & 0.03 \\
\hline \multicolumn{4}{|l|}{ Table 3. Anthropometric Parameters } \\
\hline
\end{tabular}

\begin{tabular}{|c|c|c|c|}
\hline Parameters & $\begin{array}{c}\text { Group I } \\
\text { Mean } \pm \text { SD }\end{array}$ & $\begin{array}{c}\text { Group II } \\
\text { Mean } \pm \text { SD }\end{array}$ & P-value \\
\hline $\begin{array}{c}\text { Mean CK-MB } \\
(\mathrm{mg} / \mathrm{dL})\end{array}$ & $80.32 \pm 57.55$ & $62.56 \pm 44.81$ & 0.04 \\
\hline $\begin{array}{c}\text { Mean Troponin } \\
\text { T (ng/mL) }\end{array}$ & $0.021 \pm 0.020$ & $0.014 \pm 0.0002$ & 0.03 \\
\hline $\begin{array}{c}\text { Random Blood } \\
\text { Sugar (mg/dL) }\end{array}$ & $180.04 \pm 46.75$ & $119.84 \pm 18.99$ & 0.02 \\
\hline \multicolumn{4}{|l}{ Table 4. Biochemical Parameters } \\
\hline
\end{tabular}

\begin{tabular}{|c|c|c|c|}
\hline Parameters & $\begin{array}{c}\text { Group I } \\
\text { Mean } \pm \text { SD } \\
(\mathbf{m g} / \mathbf{d L})\end{array}$ & $\begin{array}{c}\text { Group II } \\
\text { Mean } \mathbf{\text { SD }} \\
\text { (mg/dL) }\end{array}$ & P-value \\
\hline Lp(a)-C & $15.15 \pm 5.3$ & $11.93 \pm 5.7$ & 0.02 \\
\hline Total Cholesterol & $211.19 \pm 46.08$ & $189.07 \pm 44.43$ & 0.024 \\
\hline LDL Cholesterol & $140.84 \pm 45.13$ & $122.89 \pm 45.79$ & 0.22 \\
\hline HDL Cholesterol & $31.84 \pm 9.54$ & $36.48 \pm 9.20$ & 0.035 \\
\hline Triglyceride & $190.68 \pm 62.70$ & $149.31 \pm 57.91$ & 0.001 \\
\hline VLDL & $38.53 \pm 12.52$ & $29.87 \pm 11.12$ & 0.002 \\
\hline Table 5. Lp (a)-C Levels and Lipid Profile in Both Groups \\
\hline
\end{tabular}

\begin{tabular}{|c|c|c|c|c|c|c|c|}
\hline \multirow[b]{2}{*}{$\begin{array}{c}\text { ACS } \\
\text { Type }\end{array}$} & \multicolumn{2}{|r|}{ Group I } & \multicolumn{2}{|r|}{ Group II } & \multirow{2}{*}{\multicolumn{2}{|c|}{\begin{tabular}{|c|c|}
\multicolumn{2}{|c|}{ Total } \\
\multirow{N}{*}{} & $\begin{array}{l}\text { Lp(a)-C } \\
\text { Mean } \pm \\
\text { SD } \\
(\mathrm{mg} / \mathrm{dL})\end{array}$
\end{tabular}}} & \multirow[b]{2}{*}{ P-value } \\
\hline & $\mathbf{N}$ & $\begin{array}{c}\operatorname{Lp}(\mathrm{a})-\mathrm{C} \\
\operatorname{Mean} \pm \mathrm{SD} \\
(\mathrm{mg} / \mathrm{dL})\end{array}$ & $\mathbf{N}$ & $\begin{array}{c}\text { Lp(a)-C } \\
\text { Mean } \pm \text { SD } \\
(\mathrm{mg} / \mathrm{dL})\end{array}$ & & & \\
\hline NSTEMI & 15 & $12.85 \pm 4.57$ & 17 & $11.05 \pm 5.3$ & 32 & $13.5 \pm 4.4$ & 0.030 \\
\hline STEMI & 14 & $16.61 \pm 3.11$ & 17 & $11.21 \pm 5.8$ & 31 & $13.1 \pm 4.7$ & 0.001 \\
\hline UA & 21 & $15.76 \pm 7.39$ & 16 & $13.61 \pm 6.2$ & 37 & $15.9 \pm 5.1$ & 0.002 \\
\hline
\end{tabular}

\section{DISCUSSION}

In the present study considering the optimal cut-off point as $10 \mathrm{mg} / \mathrm{dL}, 82 \%$ of type 2 diabetic patients had Lp(a)-C $>10$ $\mathrm{mg} / \mathrm{dL}$ compared to $38 \%$ of non-diabetic patients. This is almost comparable with values of Salehi et al. ${ }^{6}$ (59\% in diabetic group; $42 \%$ in non-diabetic group) and Neki et al 7 in acute myocardial infarction patients. Type 2 diabetic patients had 2.15-fold risk of having higher serum lipoprotein (a) compared to non-diabetic group during acute coronary syndrome. This phenomenon may be explained by two hypotheses-

a) Diabetic group had a pre-existing high baseline serum lipoprotein (a). This might have contributed to the premature acute coronary syndrome.

b) Diabetic group underwent an accelerated acute phase reaction to acute coronary syndrome and may be a prognostic marker in such situations.

Both these hypotheses require a long-term prospective study analysing serum lipoprotein (a) serially with other parameters like HbA1c, Plasma Insulin and C-peptide being analysed to find out the correlation between these.

Atherosclerotic risk increases steadily with the increased duration of diabetes. In the present study, mean BMI and waist circumference were significantly higher in type 2 diabetic group compared to the non-diabetic group $(p<0.05)$ This is consistent with findings of Mohan et al. ${ }^{8}$ In the present study, type 2 diabetic patients had a significantly higher peak level of CK-MB and Troponin $\mathrm{T}$ as compared to the nondiabetic group ( $\mathrm{p}<0.05)$. This is comparable to the results of Gusto IIb trial. ${ }^{9}$ The diabetic individuals were not only susceptible for wider area of infarction, but also to microinfarction from repeated, multiple microemboli from a friable coronary artery thrombus. In this study serum total cholesterol, VLDL-C and triglyceride were significantly higher $(\mathrm{p}<0.05)$ in the diabetic group. LDL-C levels were not significantly different in both groups $(\mathrm{p}>0.05)$. This agrees with Haffner et al.10 In the present study all the three subgroups of ACS, there was significant difference between mean value of $\operatorname{Lp}(\mathrm{a})-\mathrm{C}$ in the diabetic and non-diabetic groups $(p<0.05)$. Neki et $a{ }^{7}{ }^{7}$ Salehi et $\mathrm{al}^{6}$ and Tseng et $\mathrm{al}^{11}$ studies show no statistically significant difference between the means of the Lp(a)-C in UA, NSTEMI or STEMI group. Enas et $\mathrm{al}^{12}$ and several other studies have also documented this elevation in $\mathrm{Lp}(\mathrm{a})$ levels in people of Indian origin when compared to other ethnic groups. Similar to the present study, higher levels of $\mathrm{Lp}(\mathrm{a})$ have been associated with CAD, especially if there is concomitant elevation of LDL levels. Levels of $\mathrm{Lp}(\mathrm{a})$ are largely genetically determined and genetic factors account for over $70 \%$ of the variation in the $\mathrm{Lp}(\mathrm{a})$ levels in the population.

In the present study, mean $\mathrm{Lp}(\mathrm{a})-\mathrm{C}$ was $13.54 \pm 5.5$ $\mathrm{mg} / \mathrm{dL}$. The range of values varied from 4.0 to $26.7 \mathrm{mg} / \mathrm{dL}$. Type 2 diabetic patients had higher Lp(a)-C levels (Mean $15.15 \pm 5.3 \mathrm{mg} / \mathrm{dL}$ ) compared to non-diabetic patients (Mean $11.93 \pm 5.7 \mathrm{mg} / \mathrm{dL}$ ). The difference of means was statistically significant $(\mathrm{p}<0.05)$. This was comparable with Mohan et al, 8 Neki et $\mathrm{al}^{7}$ and Salehi et al. ${ }^{6}$ This was because of similar patient sample and method used to measure serum Lp(a)-C.

\section{CONCLUSION}

Type 2 diabetic patients have 2.15-fold higher chance of having $\mathrm{Lp}(\mathrm{a})-\mathrm{C}>10 \mathrm{mg} / \mathrm{dL}$ than non-diabetic individuals. Higher levels of $\mathrm{Lp}(\mathrm{a})$ directly correlate with severity of myocardial injury. Elevated serum lipoprotein (a) in type 2 diabetic patients may contribute to the accelerated atherogenic/ prothrombotic state causing major adverse cardiac events. Lp(a) may contribute to the higher risk of having CAD in type 2 diabetics as compared to non-diabetics. This requires a long-term prospective study to find out the magnitude of this contribution from lipoprotein (a).

\section{REFERENCES}

[1] Antman EM, Loscalzo J. ST segment elevation myocardial infarction. In: Longo DL, Kasper DL, Jameson JL, et al. eds. Harrison's Principles of internal medicine. 19th edn. New York: McGraw Hill Companies 2015: p. 1599.

[2] Selvam A, Prabhakar. Comparative study of lipoprotein (A) level in type 2 diabetics and nondiabetic patients with ACS. IOSR Journal of Dental and Medical Science 2016;15(8):55-60. 


\section{Jemds.com}

[3] Hernandez C, Fransisco G, Chacon P, et al. Lipoprotein (A) as a risk factor for cardiovascular mortality in type 2 diabetes patients. Diabetes Care 2005;28(4):931-3.

[4] Scanu AM. Lipoprotein (A) and the atherothrombotic process: mechanistic insights and clinical implications. Curr Atheroscler Rep 2003;5(2):106-13.

[5] Rhoads GG, Dahlen G, Berg K, et al. Lp (a) lipoprotein as a risk factor for myocardial infarction. J Am Med Assoc 1986;256(18):2540-4.

[6] Salehi R, Rahbani-Nobar M, Rashtchizadeh N. Lipoprotein (A), Apo (A) phenotypes and dyslipidemia in acute coronary syndromes. Medical Journal of Islamic Academy of Science 2001;14(4):139-43.

[7] Neki AD, Durrington PN. Serum Lp (a) lipoprotein concentration and outcome of thrombolytic treatment for myocardial infarction. Br Heart J 1994;71:316-21.

[8] Mohan V, Deepa R, Harnath SP, et al. Lipoprotein (a) is an independent risk factor for coronary artery disease in NIDDM patients in South India. Diabetes Care 1998;21(11):1819-23.

\section{Original Research Article}

[9] McGuire DK, Emanuelsson H, Granger CB, et al. Influence of Diabetes mellitus on clinical outcomes across the spectrum of acute coronary syndromes. Findings from the GUSTO-IIb study. Gusto IIb Investigators. Eur Heart J 2000;21(21):1750-8.

[10] Haffner SM. Lipoprotein (a) and Diabetes: an update. Diabetes Care 1993;16(5):835-40.

[11] Tseng $\mathrm{CH}$, Chong CK, Chen CJ, et al. Lipoprotein (a) is an independent risk factor for peripheral arterial disease in Chinese Type 2 Diabetic patients in Taiwan. Diabetes Care 2004;27(2):517-21.

[12] Anand SS, Enas EA, Pogue J, et al. Elevated lipoprotein (a) levels in South Asians in North America. Metabolism 1998;47(2):182-4. 